\title{
An Assessment of farmers' perception of priority areas in oil palm production and processing in Aniocha South Local Government Area (LGA) of Delta State, Nigeria
}

\author{
Ajieh, Patrick Chuks \\ Department of Agricultural Economics and Extension, Delta State University, Asaba Campus, Asaba, Nigeria
}

\begin{abstract}
The study examined farmers' perception of priority in oil palm production and processing. The study was carried out in Aniocha South Local Government Area of Delta State, Nigeria. One hundred and sixty oil palm farmers randomly selected from eight communities were sampled. A structured interview schedule was used for data collection, while percentage, frequency count and mean scores were used to summarize data. The findings of the study show that nine priority areas are crucial to increased oil palm production and processing. These are: credit facilities for oil palm farmers, favourable land tenure policy; establishment of agro-chemical and fertilizer companies; building of mechanized processing mills at strategic locations; construction of access roads to palm plantations; providing ready markets for oil palm products; and sponsoring research on high yielding varieties and low-cost processing techniques. The study also found low technology utilization among oil palm farmers. The study recommends that the priority areas identified in this study should guide future efforts of government in revitalizing the oil palm production sub-sector. Also, oil palm farmers should be sensitized by the agricultural extension agency on the need to use improved production technologies.
\end{abstract}

Key words: Oil palm, priority areas, production technologies, processing technologies

Accepted Date: 20 June 2013

\section{Introduction}

Oil palm (Elaeis guineensis) is one of the most important economic crops in Nigeria. The cultivation of oil palm serves as a major source of income and a means of livelihood to many rural dwellers in Nigeria. According to Ibitoye, Akinsorotan, Meludu and Ibitoye (2011), the oil palm is a versatile tree crop with almost all parts of the tree being useful and of economic value. The different parts of oil palm include: the fronds, leaves, trunk and roots. These parts give a wide range of products which are of benefit to mankind.

The principal product of oil palm is the palm fruit, which is processed to obtain three commercial products. These include palm oil, palm kernel oil and palm kernel cake. The palm oil is rich in carotene and it is a precursor of vitamin A. It is also used in the manufacture of soaps and other detergents (Agwu, 2006). The palm kernel oil is used in the manufacture of margarine, cooking fats, lubricants, pomade and a source of glycerine. The residue obtained after the extraction of oil is called kernel cake, which is used in livestock feed production (Soyebo, Farinde and Dionco-Adetayo, 2005). The sludge from palm oil processing is used for making traditional soap and fertilizer. The empty bunches, fibre and shell that remain after oil extraction can be used for mulching, as manure and source of fuel.

According to Komolafe and Joy (1990), the leaves of oil palm are used for making brooms and roofing materials. The thicker leaf stalks are used for walls of village huts. The bark of the palm frond is peeled and woven into baskets while the trunk (main stem) can be split and used as supporting frames in buildings. A sap tapped from the female flower is drunk as palm wine, which is a rich source of yeast. The palm wine can be allowed to ferment and then distilled into a local gin. 


\section{Fig. 1: Uses of Oil Palm}

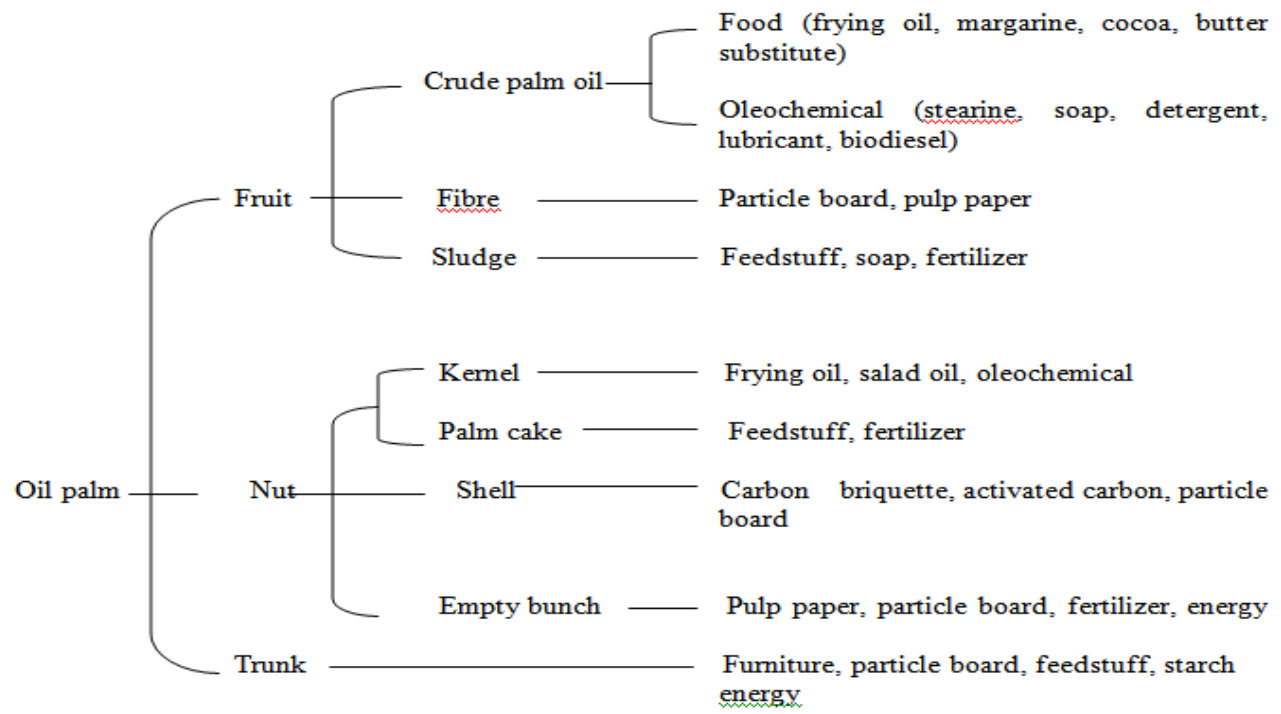

Source: A report on Palm Oil Value Chain Analysis in the Niger Delta (2011) Foundation for Partnership Initiatives in the Niger Delta (PIND)

In the 1950s and 1960s, Nigeria was a major producer of oil palm. The production of palm oil exceeded domestic consumption and the excess was exported to the world palm oil market. Then, oil palm served as a major source of foreign exchange for Nigeria. Up to 1965, Nigeria was the largest world exporter of palm oil and kernel. Nigeria's export of palm oil and palm kernel constituted 21 percent and 50 percent respectively of total world exports of these commodities between 1963 and 1965 (Food and Agriculture Organization, (FAO), 1970). Nigeria's domestic palm oil production as at 1986 was estimated to be 760,000 metric tons (Omoti, 2003).

Oil palm production in Nigeria started to dwindle in the mid-sixties as a result of many factors including overreliance on the traditional production methods, excessive tapping of palm trees for palm wine, Nigerian civil war between 1967- 1970 and the discovery of crude oil deposits in commercial quantity. Palm oil production was neglected and attention shifted to crude oil exploration and exploitation. According to FAO (1987), Nigeria's contribution to the world palm oil market fell from 39 percent between 1961 and 1965 to 11.9 percent between 1980-1984.

The dwindling fortune of Nigeria from oil palm can be seen from the low annual production growth rate from 1980-2012 as presented in Table 1

Table 1: Trends in Nigeria's palm oil production from 1980-2012 ('000mT)

\begin{tabular}{lll}
\hline Year & Production (Tons) & Growth rate $(\%)$ \\
\hline 1980 & 520 & 0.00 \\
1981 & 525 & 0.96 \\
1982 & 530 & 0.95 \\
1983 & 540 & 1.89 \\
1984 & 550 & 1.85 \\
1985 & 600 & 9.09 \\
1986 & 650 & 8.33 \\
1987 & 640 & -1.54 \\
1988 & 600 & -6.25 \\
1989 & 500 & -16.67 \\
1990 & 600 & 20.00 \\
1991 & 630 & 5.00 \\
1992 & 650 & 3.17 \\
1993 & 600 & -7.69 \\
1994 & 570 & -5.00 \\
1995 & 590 & 3.51 \\
1996 & 600 & 1.69 \\
1997 & 650 & 8.33 \\
1998 & 740 & 13.85 \\
1999 & 760 & 2.70 \\
2000 & 730 & -3.95
\end{tabular}




\begin{tabular}{lll}
2001 & 760 & 4.11 \\
2002 & 770 & 1.32 \\
2003 & 780 & 1.30 \\
2004 & 790 & 1.28 \\
2005 & 800 & 1.27 \\
2006 & 810 & 1.25 \\
2007 & 820 & 1.23 \\
2008 & 850 & 3.66 \\
2009 & 850 & 0.00 \\
2010 & 850 & 0.00 \\
2011 & 850 & 0.00 \\
2012 & 850 & 0.00 \\
\hline
\end{tabular}

Source: Adapted from Nigeria oil palm production by year. United States Department of Agriculture

Recognizing the downward trends in the production of oil palm in Nigeria, successive governments have shown concern towards revitalizing the oil palm production sub-sector so as to restore Nigeria's preeminent position as a world leader in oil palm production. Notable among efforts made by government was in April 2010, when the government of Nigeria in collaboration with the UN's Industrial Development Organisation (UNIDO) and the government of Cameroon launched a common Fund for Commodities (CFC) in order to improve the income generating potentials of oil palm in West and Central Africa. The initiative was developed by UNIDO and funding is shared between Nigeria, Cameroon, UNIDO and the private sector (PIND, 2011).

Oil palm producers and processors can assist this initiative of the government by making known priority areas that the attention of CFC should be focused. This study was therefore designed to:

(a) describe the socio-economic characteristics of oil palm farmers.

(b) ascertain the level of adoption of oil palm production and processing technologies.

(c) ascertain farmers' perception of priority areas in oil palm production and processing.

\section{Methodology}

The study was carried out in Aniocha South Local Government Area (LGA) of Delta State, Nigeria. The LGA is notable for oil palm production and processing. Eight communities within the LGA were used for the study. They include: Ogwashi-Uku, Nsukwa, Olloh, Isheagu, Ubulu-Unor, Adonta, Azagba-Ogwashi and Ubulu-Uku. Twenty oil palm farmers were randomly selected from each of the eight communities. This gave a total of 160 farmers that served as respondents of the study.

Structured interview schedule was used for data collection. Content validation of the research instrument was carried out. The instrument was piloted tested before administration to test for reliability. To ascertain respondents' level of adoption of oil palm production and processing technologies, a list of technologies used in oil palm production and processing was developed after a review of literature and respondents were requested to indicate their stage of adoption of those technologies using the 5-stage adoption process of awareness, interest, evaluation, trial and adoption. Score of 1, 2, 3, 4 and 5 was assigned to the stages respectively. Adoption score was then computed to ascertain the level of adoption. For the purpose of this study adoption was categorized as follows: (a) low adoption (for adoption score of $0-2.59$, (b) average adoption (for adoption score of $2.6-4.9$ ) and High adoption (for adoption score of $5.0-10.0$ ).

Respondents' perception of priority areas in oil palm production and processing was determined by making a list of possible areas of priority in oil palm production and processing. Respondents were then asked to rate the level of importance of the different areas using a 4-point Likert-type scale of: not important; barely important; important; and very important. Score of 1, 2, 3 and 4 was assigned to these response options respectively. The mean score of the response values which is 2.50 was taken as the cut-off point such that priority areas with mean scores of 2.50 and above were regarded as important while those with mean score below 2.50 were taken as less important priority areas.

Descriptive statistics such as mean scores, percentage, standard deviations and frequency count were used to summarize data generated for the study.

\section{Results And Discussion}

\section{Socio-economic characteristics of respondents}

Results in table 2 reveal that 74 percent of the respondents are male while 26 percents are females. This indicates that males are involved in oil palm production than the females. Women are known to be involved more in the processing and marketing of oil palm products. Majority of the respondents (81 percent) were within 
the age range of 40 years and above while the mean age of oil palm farmers in the area was found to be 46 years.

Most of the respondents (92 percent) had one form of formal education or the other ranging from primary education to post secondary education. The high literacy level of respondents could have positive effect on the adoption of oil palm technologies. Majority of the respondents (75 percent) had farming experience of between 11 years and above while the mean farming experience of the farmers was 14 years.

About 90 percent of the respondents had between $0.5-3.5$ hectares of oil palm plantation. The mean farm size of oil palm in the area was 2.6 hectares. This indicates that majority of the oil palm farmers are small-scale farmers.

Table 2: Distribution of respondents according to their socio-economic characteristics $(n=160)$

\begin{tabular}{llll}
\hline Socio-economic characteristics & Frequency & Percentage & Mean ( x ) \\
\hline Sex & 118 & 74 & \\
Male & 42 & 26 & \\
Female & & & \\
& 11 & 7 & \\
Age (years) & 19 & 12 & \\
$20-29$ & 66 & 41 & $46 \mathrm{yrs}$ \\
$30-39$ & 58 & 36 & \\
$40-49$ & 6 & 4 & \\
$50-59$ & & & \\
$60-69$ & 12 & 8 & \\
Educational attainment & 72 & 45 & \\
No formal education & 54 & 34 & \\
Primary education & 22 & 13 & \\
Secondary education & & \\
Post Secondary education & 11 & \\
Years of experience in oil palm production & 18 & \\
$1-5$ & 26 & 28 & \\
$6-10$ & 44 & 33 & \\
$11-15$ & 52 & 12 & \\
$16-20$ & 20 & & \\
$21-25$ & & & \\
Size of oil palm holdings (hectares) & 32 & 20 & \\
$0.5-1.5$ & 27 & 17 & \\
$1.6-2.5$ & 86 & 53 & \\
$2.6-3.5$ & 9 & 6 & \\
$3.6-4.5$ & 4 & 3 & \\
$4.6-5.5$ & 2 & 1 & \\
$5.6-6.5$ & & & \\
\hline
\end{tabular}

\section{Respondents' adoption of oil palm production and processing technologies}

Entries in table 3 show that there was an average adoption of the following oil palm production and processing technologies: intercropping ( $X=2.62)$; application of fertilizer $(X=2.64)$; use of herbicides to control weeds ( $X=2.54)$; mulching of each palm stand ( $X=2.65$ ); ring weeding ( $X=2.79$ ); planting leguminous crops to smother weeds $(X=2.64)$ and spraying with insecticides/pesticides $(X=2.63)$. These technologies have been known to entrance yield in the production of oil palm.

The table also revealed that there was a low adoption of the following technologies: improved oil palm varieties $(X=2.10)$; planting density ( $X=1.96)$; mechanized processing technologies $(X=2.08)$; pruning and removal of dead/diseased leaves $(X=2.21)$, and general slashing of palm plantation $(X=2.23)$. The finding of this study with respect to low adoption of these oil palm technologies is in line with the results of earlier studies. (Agwu 2006) and Okoro (1991) in separate studies reported low adoption of improved oil palm varieties, mechanized oil palm processing technique; spraying of insecticides/pesticides to control diseases and pests; and planting density by oil palm farmers. According to Agwu (2006), the low adoption of these technologies can be attributed to high cost and complexity associated with their use. The table further show that the overall mean adoption score was 2.41. This indicates a low adoption of oil palm production and processing technologies in the area. 
An Assessment of farmers' perception of priority areas in oil palm production and processing in

Table 3: Distribution of respondents according to their adoption of oil palm production and processing technologies $(\mathbf{n}=\mathbf{1 6 0})$

\begin{tabular}{|c|c|c|c|c|c|c|}
\hline Technologies & $\begin{array}{l}\text { Awarenes } \\
\text { s }\end{array}$ & $\begin{array}{l}\text { Interes } \\
\mathrm{t}\end{array}$ & Evaluation & Trial & $\begin{array}{l}\text { Adoptio } \\
\mathrm{n}\end{array}$ & $\begin{array}{l}\text { Mean } \\
\text { Adoptio } \\
\text { n Score }\end{array}$ \\
\hline Improved oil palm varieties & $70(70)$ & $38(76)$ & $25(75)$ & $20(80)$ & $7(35)$ & 2.10 \\
\hline Intercropping & $46(46)$ & $35(70)$ & $33(99)$ & $26(104)$ & $20(100)$ & 2.62 \\
\hline $\begin{array}{l}\text { Planting density }(150 \text { palms per } \\
\text { hectare) }\end{array}$ & $76(76)$ & $42(84)$ & $20(60)$ & $15(60)$ & $7(35)$ & 1.96 \\
\hline Application of fertilizer & $45(45)$ & $35(70)$ & $35(105)$ & $22(88)$ & $23(115)$ & 2.64 \\
\hline Mechanized processing techniques & $68(68)$ & $34(68)$ & $25(75)$ & $19(76)$ & $14(70)$ & 2.23 \\
\hline Planting distance $(8 \times 8 \mathrm{~m}$ btw palm) & 74(74) & $32(64)$ & $28(84)$ & $18(72)$ & $8(40)$ & 2.08 \\
\hline Use of herbicides to control weeds & $52(52)$ & $35(70)$ & $28(84)$ & $25(100)$ & $20(100)$ & 2.54 \\
\hline Mulching each palm stand & $48(48)$ & $32(64)$ & $30(90)$ & $28(112)$ & $22(110)$ & 2.65 \\
\hline Ring weeding & $40(40)$ & $33(66)$ & $32(96)$ & $30(120)$ & $25(125)$ & 2.79 \\
\hline $\begin{array}{l}\text { Planting of leguminous crops to } \\
\text { smother weeds }\end{array}$ & $45(45)$ & $35(70)$ & $33(99)$ & $27(108)$ & $20(100)$ & 2.64 \\
\hline $\begin{array}{l}\text { Pruning and removal of } \\
\text { dead/diseased leaves }\end{array}$ & $62(62)$ & $43(86)$ & $26(78)$ & $18(72)$ & $11(55)$ & 2.21 \\
\hline General slashing of palm plantation & $56(56)$ & $48(96)$ & $30(90)$ & $17(68)$ & $9(45)$ & 2.23 \\
\hline Spraying with insecticides/pesticides & $42(42)$ & $39(78)$ & $34(102)$ & $25(100)$ & $20(100)$ & 2.63 \\
\hline Overall Mean Score & & & $=$ & & & 2.41 \\
\hline
\end{tabular}

Figure in parenthesis are scores

\section{Respondents' perception of priorities in oil palm production and processing}

Data in table 4 reveal that nine of the twelve priority areas investigated by this study were considered important for oil palm production and processing. They include: credit facilities for oil palm farmers $(\mathbb{X}=2.73)$, favourable land tenure policy ( $X=2.70)$; establishment of agrochemical and fertilizer companies $(X=2.75)$; building of mechanized processing mills at strategic locations $(X=2.76$ ); construction of access roads to palm plantations $(X=2.95)$; ready markets for oil products $(X=2.59)$; favourable pricing system for oil palm products $(X=2.96)$; sponsoring research on high yielding oil palm varieties $(X=2.78)$; sponsoring research on low cost oil palm processing techniques $(X=2.88)$.

These priority areas should guide efforts at revitalizing the oil palm production sub-sector. This is because, they are crucial to the elimination of constraints to increased oil palm production such as high cost of agrochemicals (Insecticides and pesticides); unavailability of necessary agro-chemicals, high cost of fertilizers, high cost of processing in mechanized mills, high cost of labour and fluctuations in prices of palm products.

A special micro-credit programme for oil palm farmers for instance, wills enhance their capacity to purchase inputs and pay for labour charges. Also, increased research activity focusing on developing high yielding varieties and low-cost processing techniques will enable farmers produce palm fruits that contain more oil as well as process such fruits with minimum stress and at reduced cost.

Table 4: Distribution of respondents according to their perception of priority areas in oil palm production and processing $(n=160)$

\begin{tabular}{|c|c|c|c|c|c|}
\hline Priority areas & $\begin{array}{l}\text { Not } \\
\text { importa } \\
\text { nt }\end{array}$ & $\begin{array}{l}\text { Barely } \\
\text { important }\end{array}$ & Important & $\begin{array}{l}\text { Very } \\
\text { importa } \\
\text { nt }\end{array}$ & $\begin{array}{l}\text { Mean } \\
\text { Score }\end{array}$ \\
\hline Credit facilities for oil palm farmers & $37(37)$ & $28(56)$ & $35(105)$ & $60(240)$ & $2.73^{*}$ \\
\hline Storage facilities at strategic locations & $82(82)$ & $29(58)$ & $36(108)$ & $13(52)$ & 1.88 \\
\hline Subsidy on agrochemicals and fertilizers & $76(76)$ & $42(84)$ & $25(75)$ & $17(68)$ & 1.58 \\
\hline Subsidy of processing equipment/machines & $39(39)$ & $40(80)$ & $45(135)$ & $36(144)$ & 2.48 \\
\hline Favourable land tenure policy & $38(38)$ & $24(48)$ & $46(136)$ & $52(208)$ & $2.70^{*}$ \\
\hline $\begin{array}{l}\text { Establish agro-chemical and fertilizer } \\
\text { companies }\end{array}$ & $28(28)$ & $34(68)$ & $48(144)$ & $50(200)$ & $2.75 *$ \\
\hline $\begin{array}{l}\text { Build mechanical processing mills at strategic } \\
\text { locations }\end{array}$ & $29(29)$ & $36(72)$ & $40(120)$ & $55(220)$ & $2.76^{*}$ \\
\hline Construct access roads to palm plantations & $36(36)$ & $28(56)$ & $44(132)$ & $62(248)$ & $2.95 *$ \\
\hline Provide ready markets for oil palm products & $41(41)$ & $32(64)$ & $38(114)$ & $49(196)$ & $2.59 *$ \\
\hline $\begin{array}{l}\text { Favourable pricing system for oil palm } \\
\text { products }\end{array}$ & $22(22)$ & $28(56)$ & $45(135)$ & $65(260)$ & $2.96^{*}$ \\
\hline $\begin{array}{l}\text { Sponsor research on high yielding oil palm } \\
\text { varieties }\end{array}$ & $26(26)$ & $34(68)$ & $48(144)$ & $52(208)$ & $2.78 *$ \\
\hline $\begin{array}{l}\text { Sponsor research on low cost processing } \\
\text { techniques }\end{array}$ & $21(21)$ & $32(64)$ & $52(156)$ & $55(220)$ & $2.88^{*}$ \\
\hline
\end{tabular}


Key $\quad *$ Important priority areas

Figures in parenthesis are scores

\section{Conclusion}

This study examined the perception of oil palm farmers on priority areas in oil palm production and processing. Nine priority areas that are crucial to increased oil palm production and processing were identified by the study. They include: credit facilities for oil palm farmers; favourable land tenure policy; establishment of agrochemical and fertilizer companies; building of mechanized processing mills at strategic locations; providing ready markets for oil palm products; favourable pricing system for oil palm products; and sponsoring of research on high yielding varieties and low-cost processing techniques. Results of the study further showed a low adoption oil palm production and processing technologies.

Based on these findings, this study recommends that the priority areas identified by this study should guide future efforts by the government in revitalizing oil palm production and processing. Also, oil palm farmers should be sensitized by the agricultural extension agency on the need to use improved production techniques.

\section{References}

[1]. Agwu, A.E. (2006) Adoption of improved oil palm production and processing technologies in Arochukwu Local Government Area of Abia State, Nigeria. Agro-Science, Journal of Agriculture, Food Environment and Extension 5(1): 25-35.

[2]. Food and Agriculture Organisation (1987) Consultations on oil palm production, FAO, Rome.

[3]. Food and Agriculture Organisation (1970) Consultations on palm oil and palm kernel production, FAO, Rome.

[4]. Ibitoye, O.O; Akinsorotan, A.O; Meludu, N.T and Ibitoye, B.O. (2011) Factors affecting oil palm production in Ondo State of Nigeria. Journal of Agriculture and Social Research (JASR) 11(2): 97-105.

[5]. Komolafe, M.I. and Joy, D.C. (1990) Agricultural Science for Secondary Schools. Book one. Ibadan: Nigeria University Press Ltd.

[6]. Omoti, U (2003) Oil palm in Africa: Evolution during the last decade, trends and new challenges. Invited paper, XIV. International Conference: Palm oil: The alternative in oil and fats in Latin America. Cartogena Colombia. 23-26 September.

[7]. Soyebo, K.O; Farinde, A.J; and Dionco-Adetayo, E.D. (2005) Constraints of oil palm production in Ife Central Local Government Area of Osun State, Nigeria. Journal of Social Science. 10(1): 55-59 